\title{
Prevalence and profile of daily smokers seen at three primary health care units in Pelotas, southern Brazil
}

\author{
Prevalência e perfil dos fumantes diários usuários \\ de três unidades básicas de saúde de Pelotas, sul do Brasil
}

Mariane Ricardo Acosta Lopez, ${ }^{1}$ Karen Jansen, ${ }^{2}$ Luciano Dias de Mattos Souza, ${ }^{2}$ Ricardo Tavares Pinheiro, ${ }^{2}$ Elaine Tomasi, ${ }^{3}$ Ricardo Azevedo da Silva²

\begin{abstract}
Objectives: To estimate the prevalence of daily smoking among users of three primary health care units affiliated with a university hospital in the municipality of Pelotas, southern Brazil, and to identify factors associated with daily tobacco consumption.

Methods: This cross-sectional study included all individuals over 14 years of age who sought treatment at the health care units between June 29, 2009, and February 23, 2010, and lived in the area covered by the unit. Interviews were conducted during home visits to collect data on sociodemographic characteristics and health behaviors; the Mini International Neuropsychiatric Interview (MINI) was used to assess the presence of mood disorders; and a question from the Alcohol, Smoking and Substance Involvement Screening Test (ASSIST) on the daily use of tobacco in the past 3 months was used to assess smoking.

Results: The total sample comprised 1,848 individuals, mostly female $(72.9 \%)$, aged between 46 and 60 years $(28.5 \%)$, and belonging to socioeconomic class $\mathrm{C}(61 \%)$. The prevalence of daily smoking was $23.4 \%(n=432)$, and there was a statistically significant difference between men and women: 27 vs. $22.1 \%$ $(p<0.050)$.

Conclusion: Our findings confirm a high prevalence of smoking among users of primary health care units, underscoring the need for a more accurate process of diagnosis and treatment at these facilities.
\end{abstract}

Keywords: Smoking, epidemiology, prevalence, primary health care.

\section{Resumo}

Objetivos: Estimar a prevalência do uso diário de tabaco entre usuários de três unidades básicas de saúde (UBSs) vinculadas a um hospital universitário na cidade de Pelotas (RS) e identificar fatores associados ao consumo diário de tabaco.

Métodos: Participaram deste estudo transversal todos os indivíduos maiores de 14 anos que procuraram atendimento nas UBSs no período de 29 de junho de 2009 a 23 de fevereiro de 2010 e que moravam na área de abrangência da UBS. Entrevistas foram realizadas durante visitas domiciliares para coletar dados sobre características sociodemográficas e comportamentos de saúde; a entrevista estruturada Mini International Neuropsychiatric Interview (MINI) foi utilizada para avaliar a presença de transtornos de humor; e uma pergunta do instrumento Alcohol, Smoking and Substance Involvement Screening Test (ASSIST) sobre o uso diário de tabaco nos últimos 3 meses foi utilizada para avaliar o tabagismo.

Resultados: A amostra total incluiu 1.848 indivíduos, sendo a maioria do sexo feminino $(72,9 \%)$, com idade entre 46 e 60 anos $(28,5 \%)$ e pertencentes à classe socioeconômica C $(61 \%)$. A prevalência de uso diário de tabaco foi de $23,4 \%(n=432)$, com diferença estatisticamente significativa entre homens e muIheres: 27 versus $22.1 \%(p<0,050)$.

Conclusão: Nossos achados confirmam uma alta prevalência de tabagismo entre os usuários de UBSs, reforçando a necessidade de um processo de diagnóstico e tratamento mais eficiente nessas instituições.

Descritores: Tabagismo, epidemiologia, prevalência, atenção primária à saúde.

\footnotetext{
${ }_{1}$ PhD candidate, Programa de Pós-Graduação em Saúde e Comportamento, Universidade Católica de Pelotas (UCPel), Pelotas, RS, Brazil. 2 PhD. Professor, Programa de Pós-Graduação em Saúde e Comportamento, UCPel. ${ }^{3}$ PhD. Professor, Universidade Federal de Pelotas (UFPel), Pelotas, RS, Brazil. Financial support: Conselho Nacional de Desenvolvimento Científico e Tecnológico (CNPq).

Submitted Apr 17 2012, accepted for publication Jul 06 2012. No conflicts of interest declared concerning the publication of this article. Suggested citation: Lopez MR, Jansen K, Souza LD, Pinheiro RT, Tomasi E, Silva RA. Prevalence and profile of daily smokers seen at three primary health care units in Pelotas, southern Brazil. Trends Psychiatry Psychother. 2012;34(3):154-60.
} 


\section{Introduction}

Smoking is the leading preventable cause of death, and it is associated with about 6 million deaths worldwide each year. ${ }^{1}$ Tobacco consumption is currently considered a chemical addiction that exposes individuals to several toxic substances, and it has been included in the category of mental and behavioral disorders due to psychoactive substance use of the International Classification of Diseases, Tenth Revision (ICD-10), issued by the World Health Organization (WHO). ${ }^{2,3}$ The economic and societal costs associated with smoking are also high, and are estimated to reach US\$ 1 trillion by the 2030s. ${ }^{4}$ In 2002, there were one billion male and 250 million female smokers in the world, with significantly higher prevalence rates, in both sexes, in middle- to low-income countries when compared with high-income countries. Because of this increase in the consumption of tobacco in certain parts of the world, and also as a consequence of the growth of adult populations, the total number of smokers is expected to increase and to reach two billion by $2030 .^{4}$ Although some studies have reported a decrease in the prevalence of smoking in recent years, it is a consensus that the number of smokers remains high..$^{5-7}$

In Brazil, in $2008,17.5 \%$ of the population aged 15 years or more were daily smokers, corresponding to 25 million people. An analysis of the different Brazilian regions revealed that the highest percentage of tobacco users was found in the South $(19.0 \%)$, and the lowest rates, in Southeast and Central-West (a little over $16 \%$ each). Common to all regions is the greater percentage of male smokers than female ones. ${ }^{8}$ The average cigarette expenditure with manufactured cigarettes among daily smokers, calculated in Brazil based on the money spent on the last cigarette purchase, was $R \$ 78.43$. The North ( $\$$ \$ 59.97) and the Northeast ( $\$$ 59.14) showed the lowest values, whereas the South presented the highest expenditure ( $R$ \$ 98.99). When expenditures were compared according to sex, men presented an average monthly expenditure of $\mathrm{R} \$ 89.27$, compared to $\mathrm{R} \$ 62.80$ for women. ${ }^{8 *}$

Current scientific evidence has allowed to estimate the attributable risk of smoking in relation to several diseases, and has also shown that quitting smoking offers benefits even in elderly patients. It has also become evident that reducing the amount of tobacco consumed daily can decrease the risk of cardiovascular problems, respiratory symptoms, and the incidence of cancer, especially lung cancer. ${ }^{9}$ Young smokers have been shown to present a higher incidence of health problems and hospital admissions. ${ }^{10,11}$

*At the time of the study, the Brazilian real-dollar exchange rate was approximately $\mathrm{R} \$ 1.00=$ US $\$ 0.50$.
In this sense, we underscore the importance of investigating the profile of daily smokers, both to help define local and nationwide smoking prevention policies and to help reorganize and implement programs that promote smoking cessation at health care facilities. In addition to studies focusing on the profile and prevalence of smokers, investigations are needed that look into the factors associated with smoking in the primary health care system in Brazil.

The objectives of the present study were to assess the prevalence and profile of daily smokers among users of three primary health care units and to identify factors associated with the daily consumption of tobacco.

\section{Method}

This cross-sectional study was conducted between June 29, 2009, and February 23, 2010, at three primary health care units affiliated with Universidade Católica de Pelotas (UCPel), in the municipality of Pelotas, southern Brazil, namely, Fátima, Pestano, and Santa Terezinha.

Sample size was calculated using the Epi-Info 6.04d software, ${ }^{12}$ considering the goal of assessing the prevalence of smoking. We used an estimated prevalence of $20 \%$ (no lower than 18\%) and a target population of 18,000 individuals aged 14 years or more seen at the health care units. The high prevalence estimated in our study is justified by the high rates reported by previous studies conducted both in the South region ${ }^{5,8}$ and in the municipality of Pelotas. ${ }^{13}$ Considering a $95 \%$ confidence interval $(95 \% \mathrm{CI})$ and a power of $80 \%$, a total sample of 1,416 patients was calculated. Another $30 \%$ were added to compensate for losses and refusals, resulting in a total sample size of 1,842 subjects.

Subjects were selected by convenience sampling at the three health care units selected by the research team. Units were visited daily in order to obtain the list of patients seen each day; all patients were subsequently contacted and interviewed at their homes.

Patients were included in the study only after agreeing to participate and signing an informed consent form. Those who lived outside the geographical area covered by the unit and/or who manifested difficulties understanding or answering the questionnaire were excluded. Instruments were applied at the patients' homes.

The main outcome (daily smoking) was measured using a question from the Alcohol, Smoking and Substance Involvement Screening Test (ASSIST) on the frequency of tobacco use in the past 3 months. ${ }^{14}$ All individuals reporting the use of cigarettes daily or almost daily over the period assessed were considered daily smokers. Other investigations have used similar procedures to assess smoking habits. ${ }^{15}$ 
Mood disorders and alcohol dependence were assessed using the short standardized diagnostic instrument Mini International Neuropsychiatric Interview (MINI). ${ }^{16}$ The interview lasts between 15 and 30 minutes, has been designed for use in clinical and research practice, and classifies interviewees according to diagnostic criteria compatible with the Diagnostic and Statistical Manual of Mental Disorders, 4th edition (DSM-IV) ${ }^{17}$ and the ICD$10 .^{2}$ In the present study, the MINI instrument version 5.0, in Brazilian Portuguese, was used; this version was specifically designed for use in the Brazilian primary health care setting and in clinical trials.

Factors associated with smoking were assessed using a sociodemographic questionnaire comprising the following variables: age (30 years or younger, 31 to 45,46 to 60 , and 61 or older), sex (female/male), living with a partner (yes/no), education level, currently working (yes/no), presence of major diseases (yes/no), and psychiatric hospitalization in the past 12 months (yes/no). Major disease was defined as any chronic or organic condition reported by the patient after providing an affirmative answer to the question. Socioeconomic class was defined according to the classification of the Brazilian Association of Market Research Companies (Associação Brasileira de Empresas de Pesquisa, ABEP), ${ }^{18}$ based on family possessions and on the education level of the head of the family. Families were classified into socioeconomic classes $A, B, C, D$, or $E$, where $A$ is the highest and $E$ the lowest socioeconomic status.

After instrument coding, data were entered twice into the Epi-Info software, version 6.04d, with automatic error checks and consistency check. Statistical analyses were performed using the Statistical Package for the Social Sciences (SPSS), version 13. The Stata software version 9.0 was used to conduct bivariate and multivariate analyses of data, in an attempt to identify associations between daily smoking and independent variables using Poisson's regression. This statistical technique was chosen based on the high prevalence of daily smoking observed in our sample. ${ }^{19}$ Associations were considered significant when $p<0.05$, and effect measures, when the $95 \% \mathrm{CI}$ did not include 1 .

Hierarchical models were different for women and men. Among women, the model included, at the first level, health care unit, age, education level, and socioeconomic class, and at the second level, living with a partner, current working status, presence of major disease, psychiatric hospitalization, and presence of mood disorders. Among men, the first level of the hierarchical model included socioeconomic class, and the second level, presence of major disease, psychiatric hospitalization, and presence of mood disorders. Variables showing a Pearson's correlation coefficient
$<0.200$ with the outcome were maintained in the multivariate hierarchical model.

The research protocol was approved by the Ethics Committee of UCPel, and all participants diagnosed with any mental disorder according to the MINI instrument were referred for treatment at the psychiatric outpatient clinic of the university.

\section{Results}

A total of 2,278 individuals seen at the three health care units were identified by the research team. The final sample comprised 1,848 interviewees. Sample characteristics are described in Table 1.

Table 1 - Sample distribution according to demographic, socioeconomic, and psychiatric variables (Pelotas, Brazil, 2010)

\begin{tabular}{|c|c|c|}
\hline Variable & $\mathbf{n}$ & $\%$ \\
\hline \multicolumn{3}{|l|}{$\overline{S e x}$} \\
\hline Female & 1,347 & 72.9 \\
\hline Male & 501 & 27.1 \\
\hline \multicolumn{3}{|l|}{ Age (years) } \\
\hline$\leq 30$ & 434 & 23.5 \\
\hline $31-45$ & 395 & 21.4 \\
\hline $46-60$ & 526 & 28.5 \\
\hline$\geq 61$ & 493 & 26.7 \\
\hline \multicolumn{3}{|c|}{ Socioeconomic class } \\
\hline$A+B$ & 220 & 11.9 \\
\hline C & 1,128 & 61.0 \\
\hline$D+E$ & 500 & 27.1 \\
\hline \multicolumn{3}{|c|}{ Education (years) } \\
\hline $0-3$ & 505 & 27.3 \\
\hline $4-7$ & 758 & 41.0 \\
\hline $8-16$ & 585 & 31.7 \\
\hline \multicolumn{3}{|c|}{ Currently working } \\
\hline No & 1,244 & 67.3 \\
\hline Yes & 604 & 32.7 \\
\hline \multicolumn{3}{|c|}{ Lives with partner } \\
\hline No & 834 & 45.2 \\
\hline Yes & 1,013 & 54.8 \\
\hline \multicolumn{3}{|c|}{ Major disease } \\
\hline No & 910 & 49.3 \\
\hline Yes & 935 & 50.7 \\
\hline \multicolumn{3}{|c|}{ Psychiatric hospitalization (past year) } \\
\hline No & 1,686 & 91.2 \\
\hline Yes & 160 & 8.7 \\
\hline \multicolumn{3}{|c|}{ Mood disorder } \\
\hline No & 1293 & 70.0 \\
\hline Yes & 555 & 30.0 \\
\hline Total & 1,848 & 100 \\
\hline
\end{tabular}

The prevalence of daily smoking in the sample was $23.4 \%(n=432)$. There was a statistically significant difference between men and women: $27 \%$ of men vs. $22.1 \%$ of women were daily smokers $(p<0.050)$.

According to Table 2, the following variables were significantly associated with daily smoking among women: age between 31 and 45 years, currently working, psychiatric hospitalization, and presence of mood disorders. In the multivariate analysis, age between 31 and 45 years, low socioeconomic class, living with a partner, having a major disease, psychiatric hospitalization, and having mood disorders were associated with an increased risk of smoking (Table 2). 
Table 2 - Bivariate and multivariate analyses of smoking vs. demographic, socioeconomic, and psychiatric variables in women seeking primary health care assistance (Pelotas, Brazil, 2010)

\begin{tabular}{|c|c|c|c|c|}
\hline Variable & Crude PR (95\%CI) & $\mathbf{p}$ & Adjusted PR (95\%CI) & $\mathbf{p}$ \\
\hline Health care unit & & 0.594 & & 0.254 \\
\hline Fátima & Reference & & Reference & \\
\hline Pestano & $0.74(0.56-0.98)$ & & $0.73(0.55-0.97)$ & \\
\hline Santa Terezinha & $0.99(0.74-1.31)$ & & $0.88(0.66-1.17)$ & \\
\hline Age (years) & & 0.000 & & 0.000 \\
\hline$\leq 30$ & Reference & & Reference & \\
\hline $31-45$ & $1.58(1.16-2.17)$ & & $1.54(1.12-2.12)$ & \\
\hline $46-60$ & $1.27(0.93-1.73)$ & & $1.19(0.87-1.64)$ & \\
\hline$\geq 61$ & $0.40(0.26-0.63)$ & & $0.39(0.25-0.62)$ & \\
\hline Education (years) & & 0.366 & & 0.564 \\
\hline $0-3$ & Reference & & Reference & \\
\hline $4-7$ & $1.49(1.10-2.00)$ & & $1.16(0.85-1.59)$ & \\
\hline $8-16$ & $1.21(0.88-1.66)$ & & $0.97(0.67-1.39)$ & \\
\hline Socioeconomic class & & 0.059 & & 0.051 \\
\hline$A+B$ & Reference & & Reference & \\
\hline C & $1.32(0.87-1.99)$ & & $1.30(0.86-1.98)$ & \\
\hline$D+E$ & $1.51(1.22-2.34)$ & & $1.46(0.93-2.30)$ & \\
\hline Lives with partner & & 0.137 & & 0.045 \\
\hline No & Reference & & Reference & \\
\hline Yes & $0.84(0.67-1.06)$ & & $0.78(0.62-0.99)$ & \\
\hline Currently working & & 0.019 & & \\
\hline No & Reference & & & \\
\hline Yes & $1.33(1.05-1.68)$ & & & \\
\hline Major disease & & 0.996 & & 0.025 \\
\hline No & Reference & & Reference & \\
\hline Yes & $1.00(0.80-1.25)$ & & $0.67(0.47-0.95)$ & \\
\hline Psychiatric hospitalization & & 0.004 & & 0.029 \\
\hline No & Reference & & Reference & \\
\hline Yes & $1.63(1.17-2.28)$ & & $1.48(1.04-2.09)$ & \\
\hline Mood disorder & & 0.000 & & 0.000 \\
\hline No & Reference & & Reference & \\
\hline Yes & $1.77(1.41-2.22)$ & & $1.55(1.23-1.98)$ & \\
\hline
\end{tabular}

$95 \% \mathrm{CI}=95 \%$ confidence interval; $\mathrm{PR}=$ prevalence ratio.

Table 3 - Bivariate and multivariate analyses of smoking vs. demographic, socioeconomic, and psychiatric variables in men seeking primary health care assistance (Pelotas, Brazil, 2010)

\begin{tabular}{|c|c|c|c|c|}
\hline Variable & Crude PR $(95 \% \mathrm{CI})$ & $\mathbf{p}$ & Adjusted PR (95\%CI) & $\mathbf{p}$ \\
\hline Health care unit & & 0.801 & & \\
\hline Fátima & Reference & & & \\
\hline Pestano & $0.71(0.47-1.08)$ & & & \\
\hline Santa Terezinha & $1.15(0.76-1.73)$ & & & \\
\hline Age (years) & & 0.425 & & \\
\hline$\leq 30$ & Reference & & & \\
\hline $31-45$ & $1.31(0.79-2.17)$ & & & \\
\hline $46-60$ & $1.45(0.91-2.33)$ & & & \\
\hline$\geq 61$ & $0.79(0.48-1.32)$ & & & \\
\hline Education (years) & & 0.929 & & \\
\hline $0-3$ & Reference & & & \\
\hline $4-7$ & $1.24(0.83-1.87)$ & & & \\
\hline $8-16$ & $1.01(0.63-1.62)$ & & & \\
\hline Socioeconomic class & & 0.002 & & 0.174 \\
\hline$A+B$ & Reference & & Reference & \\
\hline $\mathrm{C}$ & $1.55(0.80-3.00)$ & & $1.55(0.80-3.00)$ & \\
\hline$D+E$ & $2.42(1.22-4.78)$ & & $2.30(1.16-4.58)$ & \\
\hline Lives with partner & & 0.740 & & \\
\hline No & Reference & & & \\
\hline Yes & $0.94(0.66-1.34)$ & & & \\
\hline Currently working & & 0.356 & & \\
\hline No & Reference & & & \\
\hline Yes & $1.17(0.84-1.64)$ & & & \\
\hline Major disease & & 0.156 & & 0.025 \\
\hline No & Reference & & Reference & \\
\hline Yes & $0.78(0.56-1.10)$ & & $0.67(0.47-0.95)$ & \\
\hline Psychiatric hospitalization & & 0.002 & & 0.009 \\
\hline No & Reference & & Reference & \\
\hline Yes & $2.07(1.31-3.27)$ & & $1.88(1.17-3.02)$ & \\
\hline Mood disorder & & 0.039 & & 0.092 \\
\hline No & Reference & & Reference & \\
\hline Yes & $1.47(1.02-2.13)$ & & $1.40(0.95-2.07)$ & \\
\hline
\end{tabular}

$95 \% \mathrm{CI}=95 \%$ confidence interval; $\mathrm{PR}=$ prevalence ratio. 
Table 3 shows that, among men, the following variables were statistically associated with smoking: socioeconomic class, psychiatric hospitalization, and presence of a mood disorder. In the multivariate analysis, men with a major disease and those who had already been hospitalized for psychiatric reasons showed a higher risk for the use of tobacco.

\section{Discussion}

Patient selection criteria, the use of validated instruments for the collection of data, data quality control, and interviewer blinding regarding the project aims can be considered strengths of the present study in terms of internal validity. Notwithstanding, it is important to emphasize that definitions used to assess smoking vary greatly in the literature. In addition, because we describe data of a specific group of patients, the direct comparison between our results and those of other studies becomes limited, as does the possibility to extrapolate our findings to other populations. Also, with regard to the method used here to assess smoking, it is important to justify that the present study is nested in a larger project, and therefore we used the question contained in the ASSIST test, which inquires about the use of cigarettes daily or almost every day in the past 3 months. Although this criterion is approached differently across studies, it is very similar to questions recently used in Brazilian surveys aimed at estimating the prevalence of smoking, e.g.: Do you currently smoke/ use any tobacco product on a daily basis? ("Atualmente o $\operatorname{sr}(a)$. fuma algum produto do tabaco diariamente?"). 6,8,20

Among the study limitations, some possible sources of bias should be mentioned: 1) the fact that the three health care units assessed were affiliated with a university rather than with municipal government; and 2) the high number of losses and refusals. Throughout the study period, a total of 2,278 patients seen at the three health care units were identified; of these, 430 were treated as losses, including cases in which the addresses could not be confirmed, refusals to participate, deaths, and incomplete data available on questionnaires (18.9\%). The majority of losses was caused by problems with the patients' addresses: in Brazil, in order to gain access to treatment at a health care unit, patients have to live in the area covered by that unit; as a result, some patients were found to make up inexistent addresses, which could not be confirmed later. Other limitations may include the overrepresentation of women (increased demand from female patients) and the old age of our sample.
These possible biases, however, were adjusted for in the statistical analyses.

The prevalence of smoking in our study reached $23.4 \%$, higher than the prevalence rate found in the general population $(15.1 \%)$, in the South region $(17.3 \%)$, in the state of Rio Grande do Sul $(18.8 \%)$, and in the municipality of Pelotas $(21.0 \%) .^{5,8,13}$ In the primary health care setting, smoking prevalence rates can reach $19.3 \%$, as observed in the southern state of Paraná. ${ }^{21}$ Although our data are very close or even higher than the ones listed above, they are still markedly below rates observed in other populations worldwide, such as in Australia (53.5\%), ${ }^{22}$ Santiago (45.9\%), Buenos Aires (38.6\%), Quito (29.9\%), and Mexico City (27.3\%). ${ }^{23}$ In our study, the identification of tobacco use in one-fourth of the population underscores the importance of this pathogen in the daily life of people who seek assistance at public health care units.

In addition to estimating prevalence rates, one of the aims of the present study was to describe the profile of daily smokers in the population assessed. Therefore, results were stratified according to sex. Similarly to other authors, we also observed a growing rate of female smokers in our sample. ${ }^{24,25}$ However, men still account for the highest prevalence rates and are at higher risk for daily tobacco consumption, both among people seeking assistance at health care units and in the general population. ${ }^{26-28} \mathrm{~A}$ previous study conducted in Pelotas had already reported similar findings, with prevalence rates of 25.6 and $18.5 \%$ for men and women, respectively. ${ }^{13}$

In accordance with the relevant literature, women aged 31 to 45 years showed higher rates of smoking when compared with adolescent females. ${ }^{28,29}$ We also observed a reduced use of tobacco among women aged 60 years or more. Although this finding may suggest a reduction in smoking prevalence rates with age, the phenomenon is weaker in groups coming from a lower socioeconomic status. ${ }^{30}$ In fact, poor socioeconomic conditions have been shown to be a risk factor for tobacco consumption. ${ }^{31,32}$ We speculate that the inverse relationship between socioeconomic level and smoking prevalence is due to the lack of appropriate information on the damage caused by cigarette smoking in this population. ${ }^{33}$ In the multivariate analysis, living with a partner remained associated with smoking in women; we were not able to find any previous study addressing this variable among women. Conversely, severe psychiatric disorders such as schizophrenia and mood disorders have been strongly associated with nicotine dependence: smoking rates have been reported to be two to four times higher among psychiatric patients when compared with subjects with no comorbidities. ${ }^{34,35}$ These findings are in line with our data, pointing to higher smoking prevalence 
rates among patients with mood disorders and with a history of psychiatric hospitalization.

Although our sample included more male smokers than female ones, only two variables remained statistically significant for men after the multivariate analysis. Selfreported major disease showed a significant association with smoking in both sexes, similarly to the study of Millar \& Locker, ${ }^{36}$ which reported a high prevalence of health problems among smokers. Other authors ${ }^{10,37-39}$ have also identified cigarette smoking as an important risk factor for cardiovascular disease, respiratory symptoms, neoplasms, lesions affecting the oral mucosa, and periodontal disease. In our study, having a history of psychiatric hospitalization was a risk factor for smoking among both men and women.

Our findings suggest that, although all public health care units in Brazil are officially part of the Brazilian National Tobacco Control Program, they are not undertaking sufficient interventions so as to reduce the prevalence of smokers in Brazil. One possible explanation for this shortcoming may be the fact that men are less frequent users of health care units, although they account for the highest proportion of daily smokers in the general population.

We strongly believe that our study contributes significant findings to the literature, findings that will help solve problems, propose new challenges, and help design more effective prevention strategies against tobacco use in Brazil. In addition to the strategies already in place, we suggest that new approaches be adopted in the fight against tobacco use, for example, creating policies that include smoke-free areas at the workplace, increasing cigarette prices, improving access to smoking cessation services, and recruiting professionals with expertise in providing counseling and treatment to these individuals.

\section{References}

1. World Organization Health. WHO Global Report: Mortality attributable to tobacco. Geneva: World Health Organization; 2011. Available from: http://whqlibdoc.who.int/publications/ 2012/9789241564434_eng.pdf. Accessed 2012 May 10.

2. Organização Mundial da Saúde. Classificação de transtornos mentais e de comportamento da CID-10. Porto Alegre: Artes Médicas; 1993.

3. Medeiros D. Tabagismo e transtorno mental comum na população de São Paulo-SP: um estudo a partir do inquérito de saúde no município de São Paulo (ISA-CAPITAL) [dissertação]. São Paulo: Universidade de São Paulo; 2010. http://www.teses.usp.br/teses/disponiveis/6/6132/tde13072010-112932/. Accessed 2011 Oct 15.

4. Mackay J, Eriksen M. The tobacco atlas. Hong Kong: WHO; 2002.
5. Barros AJD, Cascaes AM, Wehrmeister FC, Martínez-Mesa J, Menezes AMB. Tabagismo no Brasil: desigualdades regionais e prevalência segundo características ocupacionais. Cienc Saude Coletiva. 2011;16:3707-16.

6. Centers for Disease Control and Prevention (CDC). Current cigarette smoking prevalence among working adults-United States, 2004-2010. MMWR Morb Mortal Wkly Rep. 2011;30:1305-9.

7. World Health Organization. 10 facts on the global tobacco epidemic. http://www.who.int/features/factfiles/tobacco_ epidemic/es/index.html. Accessed 2012 May 10.

8. Instituto Brasileiro de Geografia e Estatística. Pesquisa nacional por amostra de domicílios: tabagismo, 2008. http://www.pneumologia.med.br/pdf/pesquisa_nacional_ tabagismo.pdf. Accessed 2012 May 10.

9. World Health Organization. Summary: surveillance of risk factors for noncommunicable diseases. The WHO STEPwise approach. Geneva: WHO; 2001. http://whqlibdoc.who.int/ hq/2001/WHO_NMH_CCS_01.01.pdf. Accessed 2012 May 22.

10. van de Laar R, Stehouwer C, Boreham CA, Murray L, Schalkwijk $C$, Prins $M$, et al. Continuing smoking between adolescence and young adulthood is associated with higher arterial stiffness in young adults: the Northern Ireland Young Hearts Project. J Hypertens. 2011;29:2201-9.

11. Costa JS, Reis MC, Silveira Filho CV, Linhares Rda S, Piccinini $\mathrm{F}$, Fantinel E. Prevalence of hospitalization and associated factors in Pelotas, Southern Brazil. Rev Saude Publica. 2010;44:923-33.

12. Dean AG, Dean JA, Coulombier D, Brendel KA, Smith DC, Burton $\mathrm{AH}$, et al. Epi-Info version 6.04d. A word processing database and statistics program for epidemiology on microcomputers. Atlanta: CDC; 1994.

13. Damé JD, Cesar JA, Silva SM. Tendência temporal de tabagismo em população urbana: um estudo de base populacional no Sul do Brasil. Cad Saude Publica. 2011;27:2166-74.

14. Henrique IF, Micheli D, Lacerda RB, Lacerda LA, Formigoni ML. Validação da versão brasileira do teste de triagem do envolvimento com álcool, tabaco e outras substâncias (ASSIST). Rev Assoc Med Bras. 2004;50:199-206.

15. Kuhnen M, Boing AF, Oliveira MCd, Longo GZ, Njaine K. Tabagismo e fatores associados em adultos: um estudo de base populacional. Rev Bras Epidemiol. 2009;12:615-26.

16. Amorim P. Mini International Neuropsychiatric Interview (MINI): validação de entrevista breve para diagnóstico de transtornos mentais. Rev Bras Psiquiatr. 2000;22:106-15.

17. American Psychiatric Association. Diagnostic and Statistical Manual of Mental Disorders - 4th edition (DSM-IV). Washington: APA; 1994.

18. Associação Brasileira de Empresas de Pesquisa. Critério de Classificação Econômica Brasil (CCEB). São Paulo: ABEP; 2003. http://www.abep.org/novo/Content. aspx?SectionID $=84$. Accessed 2010 Mar.

19. Coutinho L, Cazufca M, Menezes P. Métodos para estimar razão de prevalência em estudos de corte transversal. Rev Saude Publica. 2008;42:992-8.

20. Instituto Nacional do Câncer. Programa nacional de controle do tabagismo. http://www.inca.gov.br/tabagismo/frameset.asp?it em=programa\&link=introducao.htm. Accessed 2012 Jun.

21. Belinski AC, Müller EV. Prevalência de tabagismo e grau de dependência entre usuários do Centro de Atenção à Saúde (CAS) - Uvaranas, Ponta Grossa - PR. Biol Saude. 2010;16:63-73. 
22. Bryant J, Bonevski B. A survey of smoking prevalence and interest in quitting among social and community service organization clients in Australia: a unique opportunity for reaching the disadvantaged. BMC Public Health. 2011;11:827.

23. Champagne BM, Sebrie EM, Schargrodsky H, Pramparo $\mathrm{P}$, Boissonnet C, Wilson E. Tobacco smoking in seven Latin American cities: the CARMELA study. Tob Control. 2010;19:457-62.

24. Fraga $S$, Sousa $S$, Santos $A$, Mello $M$, Lunet N, Padrão $P$, et al. Tabagismo em Portugal. Arq Med. 2005;19:207-29.

25. Foll BL, George T. Treatment of tobacco dependence: integrating recent progress into practice. Can Med Assoc $\mathrm{J}$. 2007; 177:1373-80.

26. Lethbridge C, Ejku M, Vickerie J. Summary health statistics for US adults: National Health Interview Survey, 2003. Vital Health Stat. 2005;10:225.

27. Prevalence data, tobacco use, behavioral risk factor surveillance system [database on the Internet]. Atlanta: National Center for Chronic Disease Prevention and Health Promotion. http://apps.nccd.cdc.gov/BRFSS/race.asp?c at $=T$ TU\&yr $=2004 \& q k e y=4396 \&$ state $=N M$. Accessed 2011 Oct 7.

28. Ralston S, Kellett N, Williams RL, Schmitt C, North CQ. Practice-based assessment of tobacco usage in southwestern primary care patients: a Research Involving Outpatient Settings Network (RIOS Net) study. J Am Board Fam Med. 2007;20:174-80.

29. Leitão Filho FS, Galduróz JC, Noto AR, Nappo SA, Carlini $E A$, Nascimento $O A$, et al. [Random sample survey on the prevalence of smoking in the major cities of Brazil.] J Bras Pneumol. 2009;35:1204-11.

30. Filion KB, Steffen LM, Duval S, Jacobs Jr DJ, Blackburn $H$, Luepker RV. Trends in smoking among Adults from 1980 to 2009: The Minnesota Heart Survey. Am J Public Health. 2012;102:705-13. Epub 2011 Nov 28.
31. Mekrungrongwong S, Nakamura K, Kizuki M, Morita A, Somkotra T, Seino K, et al. Great inclination to smoke among younger adults coming from low-socioeconomic class in Thailand. Int Arch Med. 2011;4:29.

32. Jemal A, Thun MJ, Ries LA, Howe HL, Weir HK, Center MM, et al. Annual report to the nation on the status of cancer, 1975-2005, featuring trends in lung cancer, tobacco use, and tobacco control. J Natl Cancer Inst. 2008;100:1672-94.

33. Fakir SE, Serhier Z, Berraho M, Elrhazi K, Tachfouti N, Slama $\mathrm{K}$, et al. Knowledge and perceptions of smoking according to income level in Morocco. Am J Health Promot. 2011;25:387-91.

34. Lineberry T, Allen J, Nash J, Galardy C. Population-based prevalence of smoking in psychiatric inpatients: a focus on acute suicide risk and major diagnostic groups. Compr Psychiatry. 2009;50:526-32.

35. De Boni R, Pechansky F. [Smoking prevalence in a psychiatric unit in Porto Alegre, Brazil.] Rev Psiquiatr Rio Gd Sul. 2003; 25:475-8.

36. Millar W, Locker D. Smoking and oral health status. J Can Dent Assoc. 2007;73:155-67.

37. Torres B, Godoy I. Doenças tabaco-relacionadas. J Bras Pneumol. 2004;30:3-7.

38. Winn D. Tobacco use and oral disease. J Dental Educ. 2001;65:306-12.

39. Doll R, Peto R, Boreham J, Sutherland I. Mortality in relation to smoking: 50 years' observations on male British doctors. BMJ. 2004;328:1519. Epub 2004 Jun 22. http://www.bmj. com/content $/ 328 / 7455 / 1519$ ? view $=$ long\&pmid $=15213107$. Accessed 2012 Jun.

\section{Correspondence}

Mariane Lopez

Rua Gonçalves Chaves, 373, prédio C, sala 411C, Centro

96015-560 - Pelotas, RS - Brazil

E-mail: mariane_lop@hotmail.com

Tel.: +55-53-2128-8404 